\title{
TO COMPARE THE EFFECTIVENESS OF CONVENTIONAL INCISION AND DRAINAGE VERSES USG GUIDED PERCUTANEOUS NEEDLE ASPIRATION IN TREATMENT OF BREAST ABSCESS
}

\author{
Shanta B. Patil1, Vajreshwari M. Vagger ${ }^{2}$
}

${ }_{1}^{1}$ Associate Professor, Department of General Surgery, Mahadevappa Rampure Medical College attached to Basaveshwara Teaching and General Hospital, Kalaburgi, Karnataka, India.

2Senior Resident, Department of General Surgery, Mahadevappa Rampure Medical College attached to Basaveshwara Teaching and General Hospital, Kalaburgi, Karnataka, India.

ABSTRACT

\section{BACKGROUND}

Breast abscess can occur as a complication of mastitis. The conventional treatment of breast abscess has been incision and drainage. Minimally invasive surgery is the current trend. Conventional Incision and drainage of breast abscess leads to more pain, delayed wound healing and prolonged cessation of breast feeding. As the condition occurs in young women, scar is a major concern. This study attempts to evaluate a newer method (USG guided percutaneous needle aspiration) and compare it with the conventional method i.e. incision and drainage who presented to Basaveshwara Teaching and General Hospital, Kalaburagi.

\section{METHODS}

This is a non-randomized controlled trial. The main source of data for the study are patients admitted to Basaveshwara Teaching and General Hospital, Kalaburagi, attached to Mahadevappa Rampure Medical College, Kalaburagi, with primary diagnosis of lactational breast abscess less than $5 \mathrm{cms}$. Study period is from January 2016 to June 2017. 100 cases were included in the study and were divided into group A and group B based on the size of abscess. Sample size was taken for convenience during the study.

\begin{abstract}
RESULTS
Average age in our study was 24.5 yrs. Most common mode of presentation is pain and lump (69). Most of the patients presented within 2 weeks (92\%). 95\% were unilateral cases, 5\% were bilateral cases. In group A, 22\% had mild and annoying pain, group B $48 \%$ patients didn't have any pain, $2 \%$ suffered from mild and annoying pain. Group A- 26 patients were hospitalized for more than 5 days. Group B- 40 patients were treated on OPD basis. Breastfeeding interruption in $100 \%$ cases of incision and drainage; no breastfeeding interruption in group B. complication were residual abscess, incomplete wound healing and scar formation.
\end{abstract}

\section{CONCLUSIONS}

'Incision and dependent drainage' has been the gold standard technique in the treatment of breast abscess for years; but now the latest trend is 'USG guided percutaneous needle aspiration' which involves less postoperative pain, no cessation of breast function, results in no scar, is cosmetically beneficial and needs less hospital stay. USG guided percutaneous needle aspiration is better than incision and drainage.

HOW TO CITE THIS ARTICLE: Patil SB, Vagger VM. To compare the effectiveness of conventional incision and drainage verses usg guided percutaneous needle aspiration in treatment of breast abscess. J. Evolution Med. Dent. Sci. 2019;8(17):1358-1361, DOI: $10.14260 /$ jemds $/ 2019 / 302$

\section{BACKGROUND}

The benefits of breastfeeding are well known, and the world health organization recommends exclusive breastfeeding for first six months of life and continuing breastfeeding to age two. However, many women stop breastfeeding due to lactational breast abscesses. A breast abscess is localized accumulation of infected fluid in breast tissue 1 . Breast abscess can result as a complication of mastitis ${ }^{2}$. Mastitis is a potential complication of breast feeding that occurs more commonly in primiparous women mainly caused due to nipple piercing by a child during feeding and bacterial colonization due to improper nursing technique and incomplete emptying of the breast.3,4

'Financial or Other Competing Interest': None.

Submission 28-06-2018, Peer Review 15-03-2019,

Acceptance 23-03-2019, Published 29-04-2019.

Corresponding Author:

Dr. Vajreshwari M. Vagger,

Plot No. 10, Sri Sai Krupa,

Raghoji Layout, Bedam Road,

Kalaburgi-585105, Karnataka, India.

E-mail:vajreshwarimv@gmail.com

DOI: $10.14260 /$ jemds $/ 2019 / 302$
The reported incidence of breast abscess in lactation related mastitis is $4.8 \%-11 \%$. Despite of breast abscess becoming less in developed countries due to improved maternal hygiene, nutrition standard of living and early use of antibiotics breast abscess remain a problem among women in developing countries and form one of the surgical emergencies in lactating women one or two days condition 5 . When treatment is delayed, women is at high risk for a number of complications: mastitis may become chronic or recurrent or progress to breast abscess. Early diagnosis and treatment of mastitis is key to avoiding complications. $6,7,8$ Mastitis is most common in the first six weeks of breastfeeding and at the time of weaning. Staphylococcus aureus is predominant pathogen in postpartum breast abscess seen in up to $100 \%$ of culture confirmed cases. ${ }^{9}$ The aetiology of lactational breast abscess is milk stasis due to blockage of engorged lactiferous ducts and the following infection. The conventional treatment of breast abscess has been surgical incision and drainage. Drainage of breast abscess has undergone a gradual change from invasive to minimally invasive approach of USG guided percutaneous needle aspiration and antibiotic coverage. Antibiotics should be given early in the course of mastitis. When given within one or two days of onset, they have been shown to shorten the course of the illness and prevent complications. While 
they are less common in developed countries as a result of improved maternal hygiene, nutrition, standard of living and early administration of antibiotics, breast abscess remain a problem among women in developing countries. The treatment of breast abscesses poses a difficult clinical problem.10 Breast abscesses can be treated by repeated needle aspiration with or without ultrasound guidance. Ultrasound has been shown to be useful in diagnosis of breast abscesses, guiding needle placement during aspiration and also enables visualization of multiple abscess loculation and thus useful in needle aspiration of breast abscesses. This procedure has been used successful and is associated with less recurrence, excellent cosmetic result and has less costs. The Incision and Drainage method entails certain morbidity and may need cessation of breast function. The minimally invasive method of USG guided percutaneous needle aspiration of breast abscess is a cost-effective method of drainage of breast abscess that entails minimal morbidity and has cosmetic advantages.

\section{Aims and Objectives}

To evaluate a newer method (USG guided percutaneous needle aspiration) and compare it with the conventional method i.e. incision and drainage.

\section{METHODS}

It is a non-randomized controlled trial. The patients admitted to Basaveshwara Teaching and General Hospital Kalaburgi attached to Mahadevappa Rampure Medical College with primary diagnosis of breast abscess less than $5 \mathrm{cms}$ will be taken for this prospective study from January 2016 to June 2017. 100 cases divided in group A and group B based on size of Abscess till 50 cases in each group are obtained. Sample size was taken for convenience during the study.

All consented patients with breast abscess less than $5 \mathrm{cms}$ in puerperal group were consecutively included in the study.

\section{Inclusion Criteria}

Patients with clinical diagnosis of breast abscess $[=/<5 \mathrm{~cm}]$. Patients undergoing surgical intervention i.e., Incision and drainage or USG guided Percutaneous needle aspiration.

\section{Exclusion Criteria}

Breast abscess due to other causes like tuberculosis. A pretested proforma was used to collect relevant information (Patient data, clinical findings, lab investigations, follow-up events, etc.) from all the selected patients.

Allocation of patients to the two groups was done with the use of computer-generated random allocation numbers. The allotment process was totally independent based on serial numbers allotted by the office staff with the surgical team not being involved at any stage and blinded to the whole process as to which patient goes for which procedure. The results were assessed by a different team of physicians on follow-up with results and observations entered on individual serial numbers allotted rather than procedure, which were later matched with the specific intervention undertaken based on the serial number allotted. The compilation with analysis of data was done on conclusion of study.

\section{Data Analysis}

The statistical analysis of this study was carried out by Chi square test was used where $\mathrm{p}$ value $<0.05$ is statistically significant. Software used is SPSS version 21 .
Age distribution: The youngest patient in this study was 16 yrs. and the oldest patient was 35 years, most of the patients in our study were in age group 16 yrs. to 35 yrs. Average age in our study was 24.5 years.

\begin{tabular}{|c|c|c|}
\hline Symptoms & No. of Patients & Percentage \\
\hline Pain & 6 & $6 \%$ \\
\hline Lump with Pain & 69 & $69 \%$ \\
\hline Fever, Lump and Pain & 18 & $18 \%$ \\
\hline $\begin{array}{c}\text { Nipple Discharge, Pain, Fever } \\
\text { and Lump }\end{array}$ & 7 & $7 \%$ \\
\hline $\begin{array}{c}\text { Total } \\
\text { Table 1. Symptoms of Breast Abscess }\end{array}$ \\
\hline \multicolumn{2}{|c|}{} \\
\hline \multicolumn{2}{|c|}{}
\end{tabular}

In our series, most common mode of presentation of breast abscess is pain and lump (69\%), least common mode of presentation was solitary pain (6\%). Nipple discharge along with other symptoms in $7 \%$ of cases.

\begin{tabular}{|c|c|c|}
\hline Duration & No. of Patients & Percentage \\
\hline$<1$ Week & 40 & $40 \%$ \\
\hline 1 Week to 2 Weeks & 52 & $52 \%$ \\
\hline$>2$ Weeks & 8 & $8 \%$ \\
\hline Total & $\mathbf{1 0 0}$ & $\mathbf{1 0 0} \%$ \\
\hline \multicolumn{2}{|c|}{ Table 2. Duration of Symptoms Distribution } \\
\hline
\end{tabular}

Most of the patients with breast abscess presented within 2 weeks $(92 \%)$ in our study.

\begin{tabular}{|c|c|c|}
\hline Side & No. of Patients & Percentage \\
\hline Right & 47 & $47 \%$ \\
\hline Left & 48 & $48 \%$ \\
\hline Bilateral & 5 & $5 \%$ \\
\hline Total & $\mathbf{1 0 0}$ & $\mathbf{1 0 0} \%$ \\
\hline \multicolumn{2}{|c|}{ Table 3. Side of Breast Involvement- Distribution } \\
\hline
\end{tabular}

Most commonly unilateral breast abscess was seen (95\%), bilateral breast abscess was found in 5 patients (5\%).

\begin{tabular}{|c|c|c|c|c|}
\hline \multirow[b]{2}{*}{ Scale } & \multicolumn{2}{|c|}{ Group A } & \multicolumn{2}{|c|}{ Group B } \\
\hline & \begin{tabular}{|c|} 
No. of \\
Patients
\end{tabular} & $\%$ & $\begin{array}{c}\text { No. of } \\
\text { Patients }\end{array}$ & $\%$ \\
\hline No pain & 1 & $1 \%$ & 48 & $48 \%$ \\
\hline Mild \& annoying pain & 22 & $22 \%$ & 2 & $2 \%$ \\
\hline \begin{tabular}{|c|}
$\begin{array}{c}\text { Nagging, uncomfortable, } \\
\text { troublesome pain }\end{array}$ \\
\end{tabular} & 9 & $9 \%$ & 0 & $0 \%$ \\
\hline $\begin{array}{l}\text { Distressing, miserable } \\
\text { pain }\end{array}$ & 10 & $10 \%$ & 0 & $0 \%$ \\
\hline $\begin{array}{c}\text { Intense, dreadful, horrible } \\
\text { pain }\end{array}$ & 5 & $5 \%$ & 0 & $0 \%$ \\
\hline $\begin{array}{l}\text { Worst, unbearable, } \\
\text { excruciating pain }\end{array}$ & 3 & $3 \%$ & 0 & $0 \%$ \\
\hline Total & 50 & $100 \%$ & 50 & $100 \%$ \\
\hline \multicolumn{5}{|c|}{ Table 4. Post-Operative Pain Distribution } \\
\hline
\end{tabular}

In Group A 22\% had mild and annoying pain, 5\% patients suffered from intense dreadful and horrible pain. Whereas in Group B 48\% patients didn't have any pain, 2\% suffered from mild and annoying pain. Mean pain score in I \& D group was 3.7 and Aspiration group was 1.9. Likewise, in other groups are following. Hence, we noticed that mean pain score in aspiration method was much less. 


\begin{tabular}{|c|c|c|}
\hline No. of Days & $\begin{array}{c}\text { Group A } \\
\text { (50 Patients) }\end{array}$ & $\begin{array}{c}\text { Group B } \\
\text { (40 Patients) }\end{array}$ \\
\hline OPD & 1 & 40 \\
\hline 1 Day & 1 & 10 \\
\hline 2-4 Days & 22 & 0 \\
\hline 5-10 Days & 26 & 0 \\
\hline Total & $\mathbf{5 0}$ & $\mathbf{5 0}$ \\
\hline \multicolumn{3}{|c|}{ Table 5. Hospital Stay } \\
\hline \multicolumn{3}{|c|}{ p Value < 0.001 } \\
\hline
\end{tabular}

In conventional method of treatment incision and drainage 26 patient were hospitalized for more than 5 days. In percutaneous needle aspiration 40 patients were treated on OPD basis.

\begin{tabular}{|c|c|c|}
\hline & Incision and Drainage & Needle Aspiration \\
\hline Cases & 50 Patient & 50 Patient \\
\hline $\begin{array}{c}\text { Breastfeeding } \\
\text { Interruption }\end{array}$ & Yes & No \\
\hline \multicolumn{2}{|c|}{ Table 6. Breast Feeding Interruption } \\
\hline
\end{tabular}

Breastfeeding interruption was seen in $100 \%$ cases of incision and drainage cases. There was no breastfeeding interruption in group $b$ that is patient treated with percutaneous needle aspiration.

\section{Complications}

In our study we compiled the complications under 3 subcategories which are residual abscess (This was confirmed by ultrasound examination), and incomplete wound healing (Especially for incision and drainage procedure) and scar formation.

\begin{tabular}{|c|c|c|c|c|}
\hline \multirow{2}{*}{ Complications } & $\begin{array}{c}\text { Group A } \\
\text { (50 Patients) } \\
\text { Incision and } \\
\text { Drainage }\end{array}$ & $\begin{array}{c}\text { Group B } \\
\text { (50 Patients) } \\
\text { Needle Aspiration }\end{array}$ \\
\cline { 2 - 5 } & $\begin{array}{c}\text { No. of } \\
\text { Patients }\end{array}$ & $\%$ & $\begin{array}{c}\text { No. of } \\
\text { Patients }\end{array}$ & $\%$ \\
\hline Residual Abscess & 1 & $1 \%$ & 10 & $10 \%$ \\
\hline $\begin{array}{c}\text { Incomplete Wound } \\
\text { Healing }\end{array}$ & 10 & $10 \%$ & 0 & 0 \\
\hline Scar Formation & 48 & $48 \%$ & 1 & $1 \%$ \\
\hline \multicolumn{5}{|c|}{ pable 7. Complications Distribution } \\
\hline \multicolumn{6}{|c|}{ Ta.05 } \\
\hline
\end{tabular}

\section{DISCUSSION}

In our comparative study, we compared two groups, Group A -Incision and drainage Group B -USG guided percutaneous needle aspiration in the management of breast abscess without control group. In the current report, patients age range women aged 16-35 years mean age was 30.3 years. Hence, by observing above information and analysing we have noticed that breast abscess is more in 21- 30 yrs. In this study all the patients in both groups presented with pain as a general feature. However, the incidence of lump with pain $69 \%$. Associated fever was in 18 patients (18\%). Nipple discharge, cracked nipple, pain, fever, lump was present in 7 patients (7\%) of the total patients. Duration of symptoms less than 1 week is observed in 40 patients, between 1-2 week are 52 patients, more than 2 weeks 18 patients were observed. Most of the patients with breast abscess presented within 2 weeks (92\%) in our study, Equal incidence is seen in both breast right side abscess was seen in 47 patients and 48 patients had left side breast abscess bilateral in 5 patients. Post operatively clinical symptoms like pain and fever were assessed in the patients of breast abscess treated with aspiration and with incision and drainage. In Group A 22\% had mild and annoying pain, 5\% patients suffered from intense dreadful and horrible pain. Whereas in Group B 48\% patients didn't have any pain, $2 \%$ suffered from mild and annoying pain. Mean pain score in I \& D group was 3.7 and Aspiration group was 1.9. Likewise, in other groups are following.

Hence, we noticed that mean pain score in USG guided percutaneous needle aspiration method was much less. Most of the patients belonging to group B are day-care treatment was given which were discharged following thorough aspiration of abscess under antibiotic coverage. In group A (I\&D) majority of patients' hospital stay was 5 to 10 days, all patients were discharged by 10 days. USG guided percutaneous needle aspiration i.e. group B- There is no breastfeeding interruption. In our study, $1 \%$ patients of group A found to have residual abscess $10 \%$ of patients of group B had residual abscess, there is no complication of incomplete wound healing in group B. $10 \%$ of group A patients developed incomplete wound healing in contrast to nil wound healing complications in group $\mathrm{B}$, these incomplete wound healing where managed by extended use of antibiotics and daily dressings.

\section{In Our Study}

1. Group A

Residual abscess was found in $1 \%$ | Incomplete wound healing in 1 | Scar $-48 \%$.

\section{Group B}

Residual abscess was found in $10 \%$ | Incomplete wound healing in $0 \%$ | Scar $0 \%$

2. Most of the patients in our study were in the age group of 16-35 yrs. Average age in our study was 24.5 years.

3. In our study of 100 breast abscess cases all patients are found to be lactational breast abscess.

4. Most common mode of presentation of breast abscess was pain and lump (69\%) least common mode of presentation was solitary pain $6 \%$. Nipple discharge along with other symptoms in $7 \%$ of cases, discharge of pus here is significant.

5. Most of the patients with breast abscess presented within 2 weeks (92\%) in our study

6. Most commonly unilateral breast abscess was seen (95\%), bilateral breast abscess was found in 5 patients (5\%) Mean pain score in I \& D group was 3.7 and Aspiration group was 1.9.

\section{CONCLUSION}

'Incision and drainage' has been the gold standard technique in treatment of breast abscess for years; latest trend is USG guided percutaneous needle aspiration which causes less post-operative pain, no cessation of breast function, no scar, is cosmetically beneficial and needs less hospital stay. Through residual abscess is higher in aspiration group which required re-aspiration, for the above reasons, USG guided 
percutaneous needle aspiration appears to be the better technique.

\section{REFERENCES}

[1] Irusen H, Rohwer AC, Steyn DW, et al. Treatments for breast abscesses in breastfeeding women. Cochrane Database Syst Rev 2015;(8):CD010490.

[2] Thomsen AC, Espersen T, Maigaard S. Course and treatment of milk stasis, noninfectious inflammation of the breast and infectious mastitis in nursing women. Am J Obstet Gynecol 1984;149(5):492-5.

[3] Leibman AJ, Misra M, Castaldi M. Breast abscess after nipple piercing: sonographic findings with clinical correlation. Journal of Ultrasound in Medicine: Official Journal of the American Institute of Ultrasound in Medicine 2011;30(9):1303-8.

[4] Kaufmann R, Foxman B. Mastitis among lactating women: occurrence and risk factors. Social Sciences in Medicine 1991;33(6):701-5.
[5] Ioamnis H, Nigel JB. Acute infection of the breast. Surgery on CD-Rom 1997-2002. Medicine Publishing Company Ltd., 2002.

[6] Niebyl J, Spence MR, Parmley TH. Sporadic (nonepidemic) puerperal mastitis. J Reprod Med 1978;20(2):97-100.

[7] Marchant DJ. Inflammation of the breast. Obstet Gynecol Clin North Am 2002;29(1):89-102.

[8] Ibister C. Acute mastitis: a study of 28 cases. Med J Aust 1952;2(23):801-8.

[9] Stafford I, Hernandez J, Laibl V, et al. Community acquired methicillin-resistant Staphylococcus aures among patients with puerperal mastitis requiring hospitalization. Obstet Gynecol 2008;112(3):533-7.

[10] Sandhu GS, Gill HS, Sandhu GK, et al. Bacteriology in breast abscesses. Scholars J Applied Med Sci 2014;2(4E):1469-72. 